\title{
Analisis Prestasi Nutrien Pengkomposan Sisa Industri Sawit bagi Skala Industri dalam Tempoh Tiga Tahun
}

(Nutrient Performance Analysis for Industrial Scale Palm Oil Mill Waste Composting in Three Years Duration)

\author{
ASIS, T.,ZAHRIM, A.Y.* \& ASSIS, K.
}

\begin{abstract}
ABSTRAK
Pengkomposan tandan buah kosong (EFB) dan sisa efluen kilang (POME) merupakan pendekatan lestari bagi menukarkan EFB dan POME kepada baja kompos. Pengkomposan adalah satu proses biologi yang memerlukan pengawalan yang optimum agar nutrien yang terhasil adalah tinggi dan stabil. Cabaran utama yang dihadapi oleh industri kompos ialah untuk menghasilkan kompos yang bernutrien tinggi dan stabil. Objektif kajian ini ialah untuk menganalisis prestasi jangka panjang bagi loji kompos terpilih melalui kandungan nutrien kompos yang dihasilkan. Penyelidikan ini mengkaji prestasi tiga tahun bagi empat loji kompos di Malaysia iaitu loji kompos Merotai, loji kompos Binuang, loji kompos Tanah Merah dan loji kompos Elphil. Prestasi kandungan nutrien yang diambil kira termasuklah nitrogen, kalium, nisbah karbon kepada nitrogen, kandungan kelembapan dan agregat kompos. Sebanyak 1,465 set data nutrien dianalisis secara deskriptif. Secara keseluruhannya, prestasi kandungan nutrien kesemua loji kompos yang dikaji berjaya memenuhi keperluan minimum industri sawit. Namun terdapat kes kompos yang dihasilkan mengandungi nutrien kalium yang tidak mencapai keperluan minimum industri dan kandungan kelembapan kompos yang tinggi. Kesimpulannya, masih terdapat ruang untuk penambahbaikan dalam proses pengkomposan agar kompos yang dihasilkan mengandungi nutrien yang stabil dan memenuhi keperluan minimum industri.
\end{abstract}

Kata kunci: Kompos; nutrien; sisa efluen kilang; tandan buah kosong

\section{ABSTRACT}

Composting of empty fruit bunches (EFB) and palm oil mill effluent (POME) is a sustainable approach in converting waste into organic fertilizers. Composting is a biological process that requires optimal control in producing compost. The main challenge faced by the composting industry is to maintain final compost high nutrients. The objective of this study was to analyze the long-term performance of the selected composting plants based on the nutrient content of the final compost. Three years performance of four selected composting plants in Malaysia, namely Merotai composting plant, Binuang composting plant, Tanah Merah composting plant and also Elphil composting plant were analyzed. The nutrients content e.g. include nitrogen, potassium, carbon to nitrogen ratio; moisture content as well as compost aggregate, were considered. A total of 1,465 sets of data were analyzed descriptively. Overall, all the composting plants managed to produce composts with the nutrient content that meet the minimum requirements of oil palm plantation. But there are cases where the potassium content in the compost produced was not reaching the minimum requirements of the industry and also the moisture content of the compost produced was high. As conclusion, there is still room for improvement in the current composting process in order to produce compost where the nutrients can be maintained and meet the minimum requirements of the industry.

Keywords: Compost; empty fruit bunch; nutrients; palm oil mill effluent

\section{PENGENALAN}

Industri sawit menghasilkan dua sisa utama iaitu buah tandan kosong (EFB) dan sisa effluen kilang (POME). Malangnya, kedua-dua sisa utama ini boleh menyebabkan pencemaran alam sekitar dan masalah pengurusan sisa (Bakar et al. 2011; Schuchardt \& Stichnothe 2008). Kebiasaanya POME akan dirawat untuk menurunkan kadar keperluan biologi organisma atau (BOD) atau secara pengairan ladang dan seterusnya dilepaskan ke alur air (Wu et al.2009). Selain banyak membebaskan gas metana $\left(\mathrm{CH}_{4}\right)$, kos menguruskan POME juga agak tinggi berikutan tempoh penyimpanan yang lama di dalam kolam takungan sekitar 30 hari hingga 160 hari (Malakahmad et al. 2014) dan juga kos merawat yang tinggi.

Bagi melupuskan EFB pula, kebiasaannya dihantar ke ladang sawit sebagai sungkupan (Bakar et al. 2011). Namun masalah akan timbul ketika musim penghasilan buah sawit yang banyak akan mewujudkan timbunan EFB serta isu evakuasi. Tambahan pula kerja-kerja aplikasi EFB memerlukan penggunaan tenaga buruh yang ramai serta mengakibatkan banyak kehilangan nutrien apabila tidak diuruskan dengan cekap. 
Pengkomposan kedua-dua sisa EFB dan POME secara serentak akan membuahkan proses perawatan dan pengitaran semula sisa secara lestari (Buron et al. 2010) dan menukarkannya menjadi baja organik iaitu kompos (Singh et al. 2010). Selain itu pengkomposan juga boleh mengurangkan kebergantungan peladang kepada baja kimia. Pengkomposan sisa industri sawit akan membantu kilang sawit menguruskan sisa secara lestari dengan cara memanfaatkan 100\% EFB, 50\% POME dan 100\% kelalang dan abu dandang. Pengkomposan sisa industri sawit juga akan mengurangkan penghasilan gas metana $\left(\mathrm{CH}_{4}\right)$ juga dikenali sebagai gas rumah hijau (Buron et al. 2010; Norhasmillah et al. 2013).

Adalah menjadi cabaran kepada industri bagi menghasilkan kompos yang bernutrien tinggi dan stabil disebabkan banyak faktor yang boleh mempengaruhi kualiti nutrien. Proses pengkomposan yang terkawal sangat penting bagi memastikan kompos yang terhasil adalah matang dan mempunyai kandungan nutrien yang tinggi seperti faktor suhu, nisbah karbon kepada nitrogen, pengudaraan, pH dan kandungan kelembapan. Kajian ini bertujuan untuk mengenal pasti nutrien yang tidak memenuhi keperluan industri, faktor yang mempengaruhinya seterusnya mencadangkan penambahbaikan dalam proses pengkomposan. Kajian ini amat penting untuk membantu loji kompos menyelesaikan isu nutrien yang rendah dan tidak stabil dan menghapuskan penalti nutrien akibat kelemahan sistem pengkomposan seterusnya menjamin kesinambungan kitaran nutrien kepada pokok sawit.

\section{SPESIFIKASI KUALITI KOMPOS OLEH SIME DARBY} PLANTATION (SDP) DAN PENALTI

Prestige Central Management Sdn. Bhd. (PCM) adalah sebuah syarikat swasta yang dilantik oleh SDP untuk mereka bentuk, membina dan mengoperasikan loji pengkomposan sisa loji sawit. PCM mesti memenuhi keperluan minimum kualiti kompos yang telah ditetapkan oleh SDP. Keperluan minimum tersebut merujuk kepada nilai nutrien yang terdapat dalam kompos antaranya ialah nitrogen $(\mathrm{N})$, phosphorus $\left(\mathrm{P}_{2} \mathrm{O}_{5}\right)$, kalium $\left(\mathrm{K}_{2} \mathrm{O}\right)$ dan magnesium $(\mathrm{MgO})$ seperti yang ditunjukkan dalam Jadual 1. Setiap nutrien mempunyai dua peringkat yang dikenali sebagai Jaminan Nilai Nutrien (JNN) dana Nilai Minimum Nutrien yang Dibenarkan (NMND). JNN merujuk kepada peringkat dimana SDP akan membeli baja kompos yang dihasilkan oleh PCM, manakala NMND merujuk kepada peringkat minimum yang
SDP boleh terima untuk membeli baja kompos tersebut. Tetapi NMND hanya berkaitan kepada nitrogen dan kalium. Selain itu, SDP juga menetapkan Jaminan Nilai Agregat Nutrien (JNAN) iaitu merujuk kepada jumlah nilai keempatempat nutrien yang disebutkan. Kandungan Kelembapan (KK) dan nisbah karbon kepada nitrogen $(\mathrm{C} / \mathrm{N})$ juga sepesifikasi yang diambil kira iaitu masing-masing tidak melebihi 50\% dan 30\%.

Jika loji kompos gagal mendapatkan NMND, penalti akan dikenakan. Rebat bayaran berdasarkan tan metrik kompos yang dikeluarkan pada masa tertentu jika JNAN kurang daripada $6.5 \%$ ataupun purata bulanan nilai $\mathrm{N}$ dan $\mathrm{K}_{2} \mathrm{O}$ kurang daripada NMND iaitu $1.6 \%$ untuk $\mathrm{N}$ dan $3.0 \%$ untuk $\mathrm{K}_{2} \mathrm{O}$. Sekiranya terdapat lebih daripada satu parameter yang mencapai ketidakpatuhan, rebat hanya akan dikenakan terhadap satu nilai amaun Ringgit Malaysia (RM) yang paling tinggi. Jadual 2 menunjukkan cara pengiraan mudah bagi penalti.

\section{PENGIRAAN PENALTI NUTRIEN DAN REBAT BAYARAN}

Berdasarkan nilai nutrien dalam Jadual 2, penalti akan dikenakan jika gagal mencapai NMND $\left(\mathrm{N}\right.$ dan $\left.\mathrm{K}_{2} \mathrm{O}\right)$ mahupun JNAN (agregat).

(a) Rebat jika kurang dalam nilai agregat JNAN dikira berdasarkan kepada formula (1):

$$
\begin{aligned}
\text { Rebat }= & \text { Tan metrik kompos } \times\left(\frac{J N A-A S}{J N A}\right) \\
& \times \text { harga per tan }
\end{aligned}
$$

Contoh;

$$
\begin{aligned}
\text { Rebat }= & \text { Tan metrik kompos } \times\left(\frac{J N A-A S}{J N A}\right) \\
& \times \text { harga per tan } \\
= & 10,000 \tan \times\left(\frac{6.5-6.2}{6.5}\right) \times \mathrm{RM} 135 \\
= & \text { RM } 62,308 .
\end{aligned}
$$

(b) Rebat jika kurang nilai $\mathrm{N}$ dikira berdasarkan kepada formula (2):

$$
\begin{aligned}
\text { Rebat }= & \text { Tan metrik kompos } \times\left(\frac{J N-N S}{J N A}\right) \\
& \times \text { harga per tan }
\end{aligned}
$$

JADUAL 1. Jaminan Nilai Nutrien (JNN), Nilai Minimum Nutrien yang Dibenarkan (NMND) dan Jaminan Nilai Agregat Nutrien (JNAN)

\begin{tabular}{cccccc}
\hline $\begin{array}{c}\text { Tahap nutrien lembapan } \\
\text { asas kering }(\%)\end{array}$ & $\begin{array}{c}\text { Nitrogen, } \\
\mathrm{N}\end{array}$ & $\begin{array}{c}\text { Fosforus, } \\
\mathrm{P}_{2} \mathrm{O}_{5}\end{array}$ & $\begin{array}{c}\text { Kalium, } \\
\mathrm{K}_{2} \mathrm{O}\end{array}$ & $\begin{array}{c}\text { Magnesium, } \\
\mathrm{MgO}\end{array}$ & JNAN \\
\hline JNN & 1.8 & 0.5 & 3.4 & 0.8 & 6.5 \\
NMND & 1.6 & $\mathrm{~TB}$ & 3.0 & $\mathrm{~TB}$ & $\mathrm{~TB}$ \\
\hline
\end{tabular}

TB $=$ Tidak Berkaitan 
JADUAL 2. Jaminan Nilai Nutrien (JNN), Nilai Minimum Nutrien yang Dibenarkan (NMND) dan Jaminan Nilain Agregat Nutrien (JNAN) lawan Nutrien Sebenar, Kandungan Kelembapan (KK) dan Nilai Agregat Sebenar (AS)

\begin{tabular}{cccccc}
\hline & Nitrogen, & Fosforus, & Kalium, & Magnesium, & JNAN \\
& $\mathrm{N}$ & $\mathrm{P}_{2} \mathrm{O}_{5}$ & $\mathrm{~K}_{2} \mathrm{O}$ & $\mathrm{MgO}$ & \\
\hline JNN $(\%)$ & 1.8 & 0.5 & 3.4 & 0.8 & $6.5(\mathrm{JNA})$ \\
NMND $(\%)$ & $1.6(\mathrm{JN})$ & $\mathrm{TB}$ & $3.0(\mathrm{JK})$ & $\mathrm{TB}$ & TB \\
Nilai nutrien sebenar $(\%)$ & $1.5(\mathrm{NS})$ & 0.6 & $2.9(\mathrm{KS})$ & 1.2 & $6.2(\mathrm{AS})$ \\
KK $(\%)$ & \multicolumn{2}{c}{ Jaminan $=50$, Sebenar $=53$} \\
\hline
\end{tabular}

TB $=$ Tidak Berkaitan

Contoh;

$$
\begin{aligned}
\text { Rebat }= & \text { Tan metrik kompos } \times\left(\frac{J N-N S}{J N A}\right) \\
& \times \text { harga per tan } \\
= & 10,000 \tan \times\left(\frac{1.6-1.5}{6.5}\right) \times \text { RM135 } \\
= & \text { RM } 20,769 .
\end{aligned}
$$

(c) Rebat jika kurang nilai $\mathrm{K}_{2} \mathrm{O}$ dikira berdasarkan kepada formula (3):

$$
\begin{aligned}
\text { Rebat }= & \text { Tan metrik kompos } \times\left(\frac{J N-N S}{J N A}\right) \\
& \times \text { harga per tan }
\end{aligned}
$$

Contoh;

$$
\begin{aligned}
\text { Rebat }= & \text { Tan metrik kompos } \times\left(\frac{J N-N S}{J N A}\right) \\
& \times \text { harga per tan } \\
= & 10,000 \tan \times\left(\frac{3.0-2.9}{6.5}\right) \times \text { RM135 } \\
= & \text { RM } 20,769 .
\end{aligned}
$$

Berdasarkan tiga pengiraan tersebut, SDP akan mengenakan penalti kepada loji kompos (tuntutan rebat) terhadap kes (a) sahaja iaitu sebanyak RM62,308 untuk bulan tersebut iaitu nilai tertinggi bagi tiga contoh pengiraan di atas.

\section{PENGIRAAN PENALTI KANDUNGAN KELEMBAPAN DAN REBAT BAYARAN}

Jika purata KK melebihi jaminan kandungan kelembapan $(50 \%)$, maka nilai nutrien yang dilaporkan pada setiap bulan akan digunakan untuk menentukan jumlah rebat bagi KK sebenar. Pengiraan rebat KK adalah menggunakan formula (4) berikut;

$$
\begin{aligned}
\text { Rebat }= & (\% \text { KK sebenar }-\% \text { KK Jaminan }) \\
& \times(\tan \text { metrik kompos }) \times(\text { harga per tan }) .
\end{aligned}
$$

Contoh;

$$
\begin{aligned}
\text { Rebat }= & (\% \text { KK sebenar }-\% \text { KK Jaminan }) \\
& \times(\text { tan metrik kompos }) \times(\text { harga per tan }) \\
= & (53 \%-50 \%) \times(10,000) \times(\text { RM } 135) \\
= & \text { RM } 40,500.00 .
\end{aligned}
$$

\section{PENGIRAAN PENALTI C/N DAN REBAT BAYARAN}

Manakala bagi nisbah $\mathrm{C} / \mathrm{N}$ pula, jika nilai puratanya melebihi 30, semua pengeluaran kompos yang telah dihantar ke ladang pada bulan tersebut tidak akan mendapat apa-apa bayaran. Pengiraan adalah berdasarkan kepada formula (5) berikut.

$$
\begin{aligned}
\text { Kompos } \mathrm{C} / \mathrm{N}>30= & (\text { tan metrik kompos }) \\
& \times(\text { harga per tan }) \times(0) .
\end{aligned}
$$

\section{KAWASAN KAJIAN}

Prestasi nutrien jangka panjang bagi empat loji kompos telah dianalisis dalam kajian ini. Merujuk kepada Rajah 1, dua loji kompos terletak di daerah Tawau, Sabah (Merotai dan Binuang), manakala dua lagi di Semenanjung Malaysia (Elphil, Perak dan Tanah Merah, Negeri Sembilan). Daripada empat loji kompos tersebut, loji kompos Merotai adalah yang terbesar. Loji kompos Merotai telah direka untuk memproses kira-kira 38,500 tan metrik EFB, 96,250 m³ POME dan menghasilkan 27,000 tan metrik kompos setahun. Saiz batas selebar 8 meter, panjang 56 meter dan tinggi 2 hingga 3 meter yang berkapasiti 800 tan metrik bagi setiap batas.

\section{KAEDAH PENGKOMPOSAN}

Proses pengkomposan bermula dengan kemasukan EFB dan pembentukan batas pada hari pertama, proses inokulum hari ke-1 dan ke-5, diikuti penyiraman POME bermula hari ke-2 sehingga hari ke-35, pemeraman kira-kira 10 hari bermula hari ke-36 sehingga hari ke-45. Proses pembalikan batas dibuat menggunakan mesin jengkaut pada setiap 5 hari iaitu hari ke-5, 10, 15, 20, 25, 30 dan 43 untuk tujuan pengudaraan. Manakala kerja mendebukan yang bertujuan untuk memecahkan kompos kepada bentuk dan saiz yang sekata dibuat pada hari ke-36 dan hari ke-40. 
Selepas 45 hari pemprosesan kompos, sampel akan diambil dan dihantar ke makmal penyelidikan Sime Darby untuk dianalisis sementara kompos dihantar ke ladang. Keputusan hasil analisis akan diemelkan kepada SDP ladang dan loji kompos untuk rekod dan kiraan penalti. Prosedur piawai operasi ini telah dikemaskini berbanding kajian (Zahrim \& Asis 2010) yang dilakukan pada sistem terbuka iaitu tidak berbumbung kepada sedikit perubahan dalam sistem tertutup di bawah bumbung.

\section{METOD: ANALISIS DESKRIPTIF}

Prestasi loji kompos yang terlibat diukur melalui empat parameter iaitu kandungan nutrien seperti nitrogen dan kalium, nisbah karbon kepada nitrogen, kandungan kelembapan dan juga agregat kompos. Agregat merujuk kepada jumlah nilai nutrien (nitrogen, fosforus, kalium dan magnesium). Prestasi jangka panjang tersebut dianalisis menggunakan statistik deskriptif. Spesifikasi kualiti kompos yang telah ditetapkan oleh SDP dijadikan penanda aras bagi prestasi kompos jangka panjang. Data sekunder yang dikumpul melalui rekod loji kompos merupakan keputusan analisis nutrien yang telah dibuat di makmal penyelidikan Sime Darby. Bilangan set sampel nutrien yang digunakan ialah sebanyak 1,465 rangkuman data Januari 2013 sehingga Ogos 2015 yang diambil daripada empat loji kompos terpilih seperti yang ditunjukkan pada Rajah 1.

\section{HASIL DAN PERBINCANGAN}

\section{NITROGEN}

Merujuk kepada Jadual 1, NMND bagi $\mathrm{N}$ ialah 1.6 (nilai ditunjukkan dalam garisan putus-putus pada Rajah 2), manakala JNN ialah 1.8. Jadi berdasarkan Jadual 3 dan Rajah 2 keseluruhan min bagi $\mathrm{N}$ mewakili kesemua loji kompos ialah 1.93 (nilai ditunjukkan dalam garisan penuh pada Rajah 2) lebih tinggi berbanding NMND dan JNN. Namun masih terdapat sesetengah kes dimana loji kompos gagal mendapatkan keperluan minimum (NMND) terutamanya pada tahun 2014.

Dalam tahun 2015 pula kebanyakan loji kompos telah memperbaiki prestasi mereka dengan menurunkan bilangan kes nilai $\mathrm{N}$ yang kurang daripada 1.6. Secara asasnya sumber bagi $\mathrm{N}$ ialah daripada sumber protein seperti najis dan kumbahan. Tapi dalam kes pengkomposan EFB-POME sumber $\mathrm{N}$ yang utama datangnya daripada POME. Dalam usaha meningkatkan nilai N, loji kompos sentiasa membuat aktiviti siraman POME pada hari ke-2 hingga hari ke-35 proses pengkomposan dan disusuli

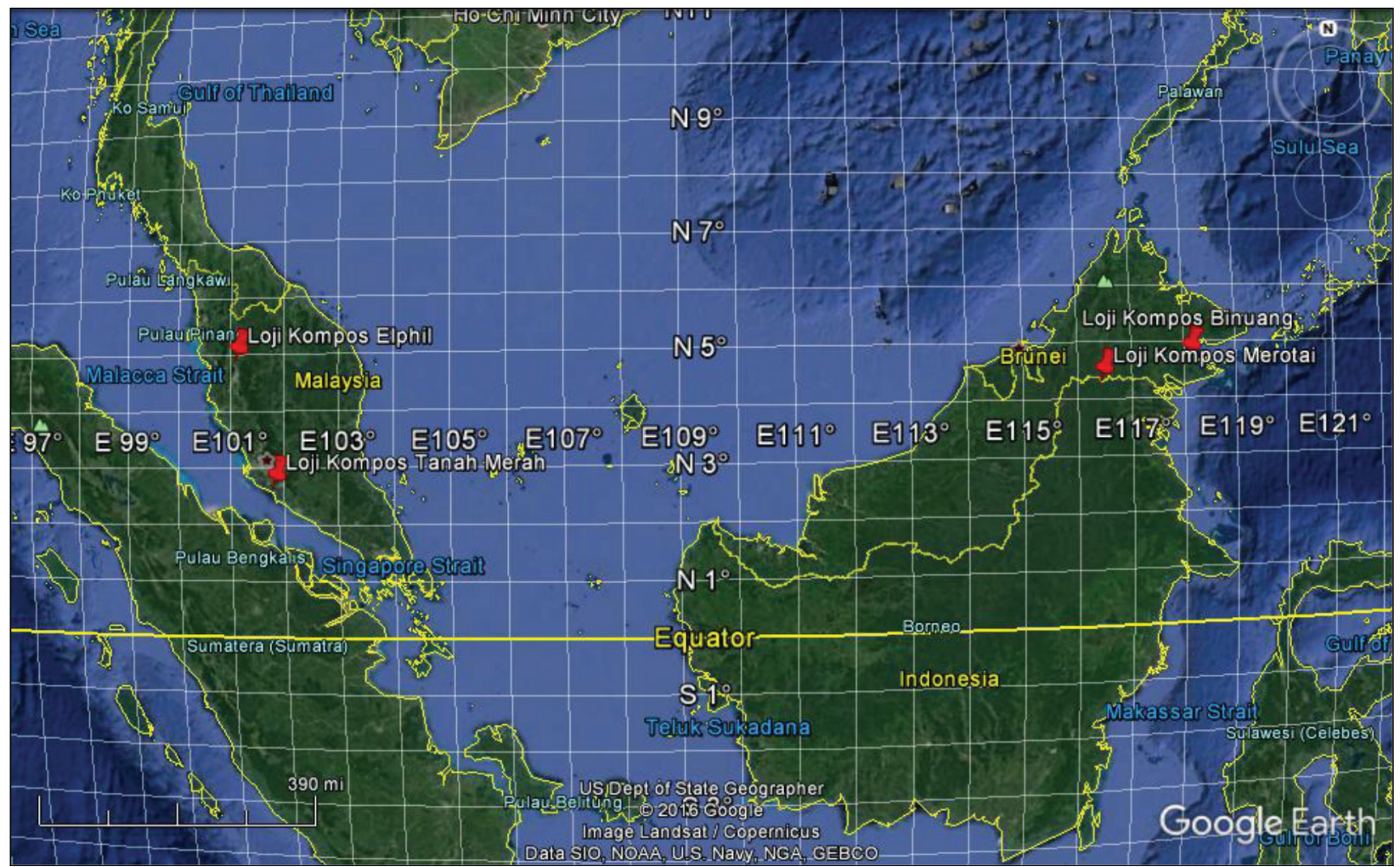

Sumber: Google Earth

Petunjuk:

Loji Kompos Elphil, Sg. Siput, Perak (4.890046, 101.090915)

Loji Kompos Tanah Merah, Lukut, Port Dicson, Negeri Sembilan $(2.651846,101.792176)$

Loji Kompos Merotai, Tawau, Sabah $(4.370351,117.834280)$

Loji Kompos Binuang, Kunak, Sabah (4.703654, 118.058682) 
JADUAL 3. Nilai nitrogen mengikut loji kompos bagi tahun 2013-2015

\begin{tabular}{llccccccc}
\hline & & \multicolumn{9}{c}{ Nitrogen, } \\
& & & & & & & Sisihan \\
& & Minimum & Maksimum & Median & Mod & Min & Piawai & Standard \\
\hline Loji & Binuang & 1.45 & 2.91 & 1.76 & 1.73 & 1.82 & .23 & .01 \\
& Merotai & 1.48 & 3.19 & 1.74 & 1.62 & 1.80 & .28 & .01 \\
& Tanah Merah & .70 & 2.94 & 1.88 & 1.85 & 1.92 & .43 & .03 \\
& Elphil & 1.10 & 3.35 & 2.15 & 1.86 & 2.17 & .41 & .02 \\
& Keseluruhan & .70 & 3.35 & 1.82 & 1.62 & 1.93 & .37 & .01 \\
\hline
\end{tabular}

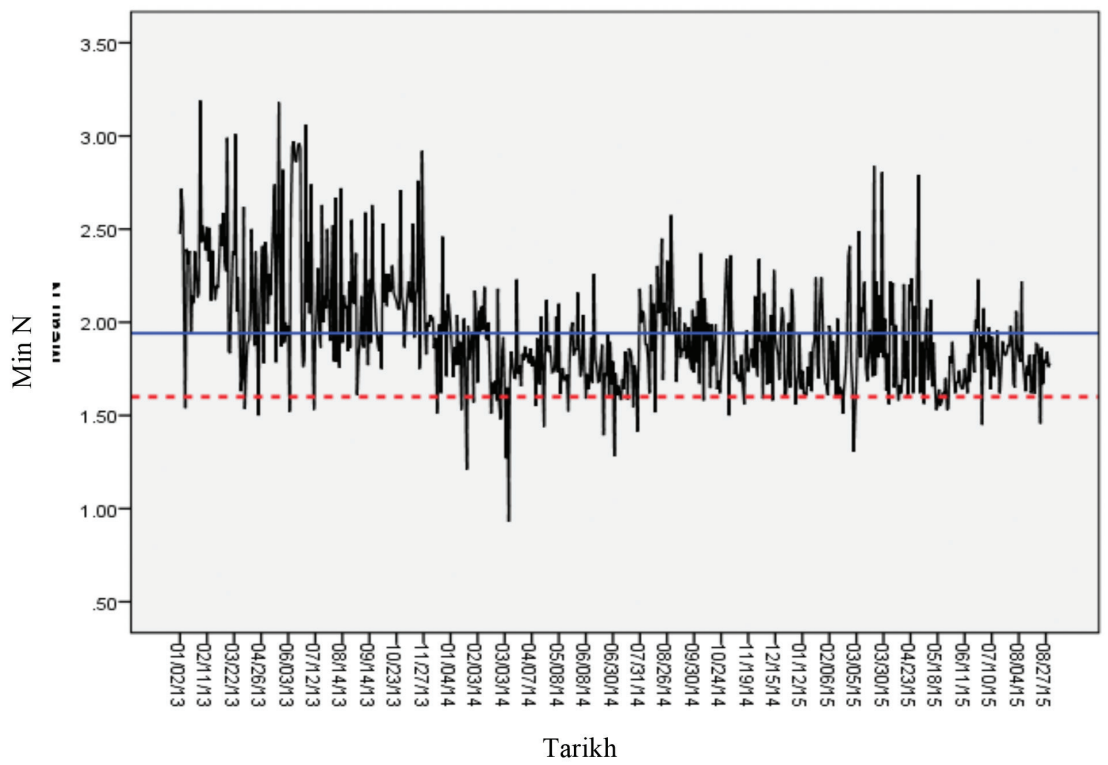

RAJAH 2. Min keseluruhan nitrogen yang dihasilkan oleh empat loji kompos (2013-2015)

tempoh pematangan pada hari ke-36 sehingga hari ke40. Zainudin et al. (2013) mendapati bahawa aktiviti penyiraman enap cemar POME yang berterusan akan membantu membekalkan nutrien yang tinggi $(\mathrm{N}=2.5 \%)$, seterusnya mengurangkan tempoh masa pengkomposan. Jusoh et al. (2013) juga melaporkan bahawa peningkatan $\mathrm{N}$ disebabkan biasanya aktiviti bakteria mengikat nitrogen pada masa penghujung pengkomposan (pematangan) dan juga disebabkan berat bersih terbebas bersama organik karbon sebagai $\mathrm{CO}_{2}$ semasa proses pengkomposan berlaku.

\section{KALIUM}

JNN bagi Kalium ialah 3.4, manakala NMND ialah 3.0 (Nilai NMND ditunjukkan oleh garisan putus-putus pada Rajah 3). Merujuk kepada Jadual 4 dan Rajah 3, min keseluruhan bagi kempat-empat loji kompos ialah 4.2 (Nilai ditunjukkan pada garisan penuh pada Rajah 3) yang menunjukkan nilai tersebut lebih tinggi berbanding JNN dan NMND seterusnya memenuhi spesifikasi keperluan nutrien kompos. Walau bagaimanapun, terdapat keputusan yang gagal pada tahun 2013 dan 2014 menunjukkan nilai $\mathrm{K}_{2} \mathrm{O}$ masih naik turun disebabkan mod keseluruhan hanya 3.08 melepasi sedikit nilai NMND. Satu petanda baik apabila pada tahun 2015 bilangan kes nilai NMND semakin berkurangan menunjukkan proses pembaikan telah dijalankan. Proses penambahbaikan yang dijalankan adalah dengan mengitar semula lebihan POME. $\mathrm{K}_{2} \mathrm{O}$ yang mudah larut dengan air akan larut melalui lebihan POME (Bhattacharyya et al. 2007; Jusoh et al. 2013) ketika aktiviti penyiraman POME. Hal ini menyebabkan loji kompos menyedari kepentingan mengitar semula lebihan POME kerana mengandungi nutrien yang tinggi.

Semasa aktiviti penyiraman POME, sesetengah nutrien $\mathrm{K}_{2} \mathrm{O}$ akan hilang daripada batas melalui lebihan POME yang larut lesap dan dikumpulkan dalam kolam takungan bahan larut lesap untuk dikitar semula ke batas (Veijalainen et al. 2007) terutamanya pada penghujung proses penyiraman POME iaitu pada hari ke-30 sehingga hari ke-35. Selain itu, penggunaan abu dandang juga dimasukkan pada hari ke-30 dan ke atas amat baik kerana mengandungi $\mathrm{K}_{2} \mathrm{O}$ yang tinggi. Kavitha et al. (2013) melaporkan bahawa nilai $\mathrm{K}_{2} \mathrm{O}$ EFB ialah $1.28 \%$ telah meningkat kepada $1.96 \%$ dengan kaedah pengkomposan $\mathrm{EFB}+$ POME. Jusoh et al. (2013) juga melaporkan melalui kajian kecekapan pengkomposan menggunakan mikrob dan tanpa mikrob menunjukkan $\mathrm{K}_{2} \mathrm{O}$ telah meningkat masing-masing daripada $1.1 \%$ menjadi $1.7 \%$ dan $1.2 \%$ 


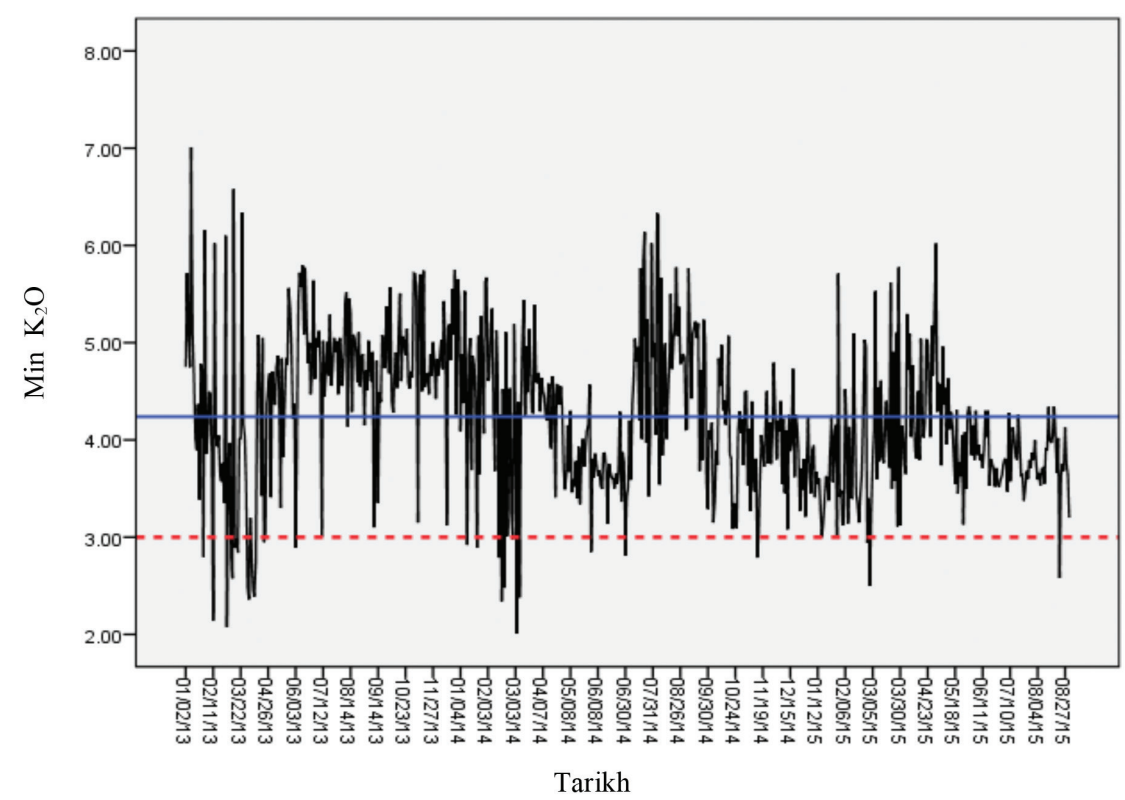

RAJAH 3. Min keseluruhan kalium yang dihasilkan oleh empat loji kompos (2013-2015)

JADUAL 4. Nilai kalium mengikut loji kompos bagi tahun 2013-2015

\begin{tabular}{clccccccc}
\hline & \multicolumn{9}{c}{ Kalium, $\mathrm{K}_{2} \mathrm{O}$} \\
\cline { 3 - 8 } & & Minimum & Maksimum & Median & Mod & Min & $\begin{array}{c}\text { Sisihan } \\
\text { piawai }\end{array}$ & $\begin{array}{c}\text { Min ralat } \\
\text { piawai }\end{array}$ \\
\hline \multirow{4}{*}{ Loji } & Binuang & 1.75 & 8.94 & 4.09 & 3.49 & 4.32 & 1.30 & .07 \\
& Merotai & 1.86 & 6.38 & 4.03 & 3.21 & 4.02 & .88 & .04 \\
& Tanah Merah & .54 & 7.93 & 4.02 & 4.13 & 4.16 & 1.09 & .07 \\
& Elphil & 2.70 & 7.62 & 4.47 & 4.07 & 4.55 & .90 & .04 \\
& Keseluruhan & .54 & 8.94 & 4.16 & 3.08 & 4.26 & 1.06 & .03 \\
\hline
\end{tabular}

menjadi $1.4 \%$ selepas pengkomposan jerami padi pada hari ke-90.

\section{NISBAH KARBON KEPADA NITROGEN}

Nisbah karbon kepada nitrogen $(\mathrm{C} / \mathrm{N})$ adalah penawaran jumlah karbon berkadaran dengan jumlah nitrogen. Jika nisbah $\mathrm{C} / \mathrm{N}$ terlalu tinggi, proses pengkomposan akan menjadi perlahan. Tetapi jika nisbah $\mathrm{C} / \mathrm{N}$ rendah, $\mathrm{N}$ akan terbebas sebagai gas ammonia (Li et al. 2013; Yan et al. 2015). Jusoh et al. (2013) melaporkan kebanyakan karbon (C) diserap oleh mikroorganisma dan ditukarkan kepada gas karbon dioksida $\left(\mathrm{CO}_{2}\right)$ semasa proses metabolisma sel-sel. Manakala baki $\mathrm{C}$ akan berubah menjadi bentuk membran dan protoplasma seterusnya merendahkan nisbah $\mathrm{C} / \mathrm{N}$ diakhir proses pengkomposan. Permulaan ideal untuk pengkomposan aerobik ialah 25-31:1 (Yan et al. 2015). Keputusan kajian ini menunjukkan min keseluruhan ialah 20.26 seperti yang ditunjukkan dalam Jadual 5. Manakala mod keseluruhan juga ialah 20.41 adalah sangat baik bagi pengkomposan 45 hari berbanding dengan hasil (Ooi 2011) keputusan nisbah $\mathrm{C} / \mathrm{N}$ pada hari ke 45-51 hanyalah 37 dan selepas hari ke 80-86 mendapat nisbah C/N 28. Rajah 4 menunjukkan beberapa sampel telah melebihi had penetapan nisbah $\mathrm{C} / \mathrm{N}$ yang disumbangkan oleh loji kompos Tanah Merah dan Elphil iaitu masing-masing 54.38 dan 35.03. Nilai tersebut agak ganjil yang kebiasaannya digambarkan sebagai kompos yang belum matang atau proses pengkomposan masih belum selesai. Namun, bermula ogos 2014 sehingga 2015 tidak terdapat lagi nisbah C/N yang melebihi 30 . Proses penambahbaikan yang dilakukan dengan mematuhi piawai prosedur operasi proses pengkomposan yang diberikan. Secara umumnya loji kompos tiada masalah mendapatkan nisbah $\mathrm{C} / \mathrm{N}=30$ dan ke bawah bagi kompos yang matang.

\section{KANDUNGAN KELEMBAPAN}

Nilai kandungan kelembapan (KK) normal bagi kompos matang ialah $50 \%$ dan nilai yang ditetapkan oleh SDP juga tidak melebihi 50\%. Min keseluruhan bagi KK ialah $43.93 \%$ (ditunjukkan pada garisan penuh pada Rajah 5) tetapi modnya ialah $48.20 \%$ menghampiri penalti. Selain itu KK merupakan isu besar yang perlu diatasi bagi mencapai nilai ideal iaitu 50\% ke bawah (ditunjukkan pada garisan putusputus pada Rajah 5). Sepanjang tahun 2013 sehingga 2015 trend KK hampir sama dengan KK lebih 50\% sentiasa terjadi 


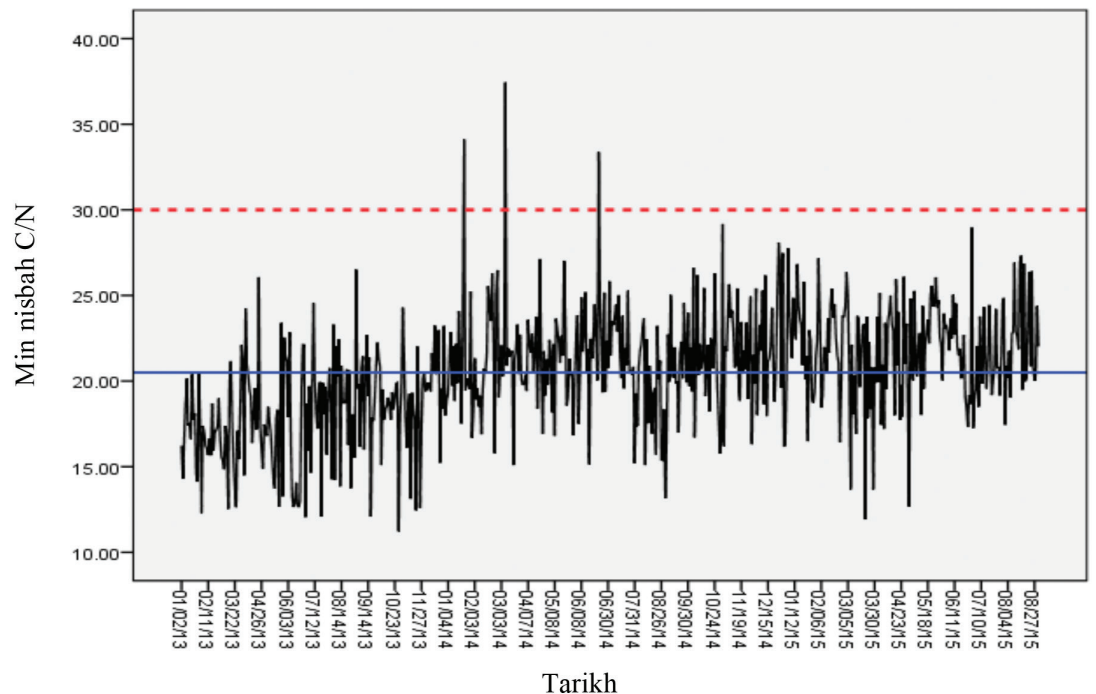

RAJAH 4. Min keseluruhan nisbah karbon kepada nitrogen yang dihasilkan oleh empat loji kompos (2013-2015)

JADUAL 5. Nilai nisbah karbon kepada nitrogen mengikut loji kompos bagi tahun 2013-2015

\begin{tabular}{llccccccc}
\hline & \multicolumn{1}{c}{} & \multicolumn{9}{c}{ Nisbah C/N } \\
\cline { 3 - 9 } & & Minimum & Maksimum & Median & Mod & Min & $\begin{array}{c}\text { Sisihan } \\
\text { piawai }\end{array}$ & $\begin{array}{c}\text { Min ralat } \\
\text { piawai }\end{array}$ \\
\hline \multirow{4}{*}{ Loji } & Binuang & 12.94 & 29.03 & 22.95 & 21.51 & 22.52 & 3.10 & .17 \\
& Merotai & 11.93 & 29.13 & 22.42 & 22.22 & 22.06 & 3.30 & .16 \\
& Tanah Merah & 11.94 & 54.38 & 19.48 & 13.35 & 20.50 & 5.28 & .33 \\
& Elphil & 9.47 & 35.03 & 16.78 & 15.17 & 17.41 & 3.81 & .19 \\
& Keseluruhan & 9.47 & 54.38 & 20.98 & 20.41 & 20.62 & 4.35 & .11 \\
\hline
\end{tabular}

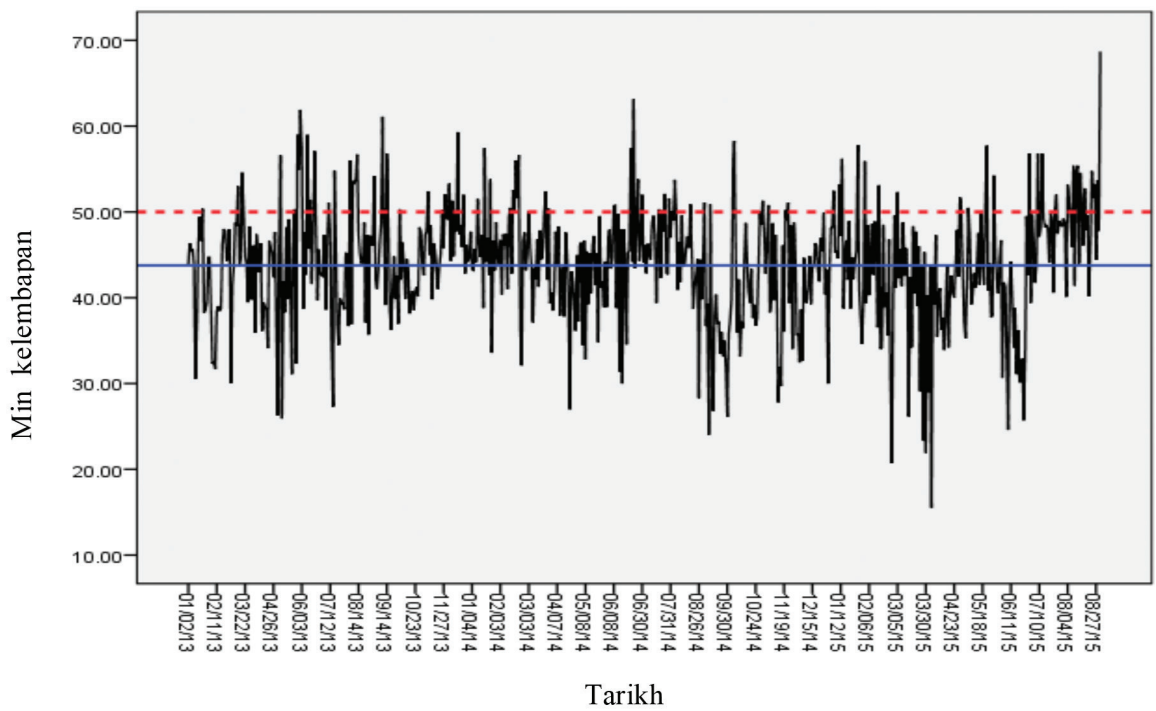

RAJAH 5. Min keseluruhan kandungan kelembapan yang dihasilkan oleh empat loji kompos (2013-2015)

disebabkan kegagalan proses pengkomposan menyejatkan kelembapan (Jadual 6). Bagaimanapun, proses ini boleh diatasi dengan mengawal kadar pengambilan POME, memperbanyakkan putaran atau dengan menggunakan proses timbunan dengan pengudaraan paksa (Zahrim 2005).
Proses pemeraman hanya 10 hari masih tidak mencukupi untuk menurunkan KK kepada bawah $50 \%$. Ooi (2011) melaporkan bahawa kompos mengambil masa 55 hari untuk menurunkan KK $72 \%$ kepada $50 \%$ pada hari ke-31 dan hari ke-86. Kandungan kelembapan yang tinggi $(>50 \%)$ bukan sahaja menambahkan berat kompos 
JADUAL 6. Kandungan kelembapan mengikut loji kompos bagi tahun 2013-2015

\begin{tabular}{|c|c|c|c|c|c|c|c|c|}
\hline & & \multicolumn{7}{|c|}{ Kandungan kelembapan, KK } \\
\hline & & Minimum & Maksimum & Median & Mod & Min & $\begin{array}{l}\text { Sisihan } \\
\text { piawai }\end{array}$ & $\begin{array}{c}\text { Min ralat } \\
\text { piawai }\end{array}$ \\
\hline \multirow{5}{*}{ Loji } & Binuang & 15.30 & 68.70 & 44.75 & 46.80 & 42.30 & 10.63 & .57 \\
\hline & Merotai & 15.70 & 68.40 & 45.45 & 44.20 & 44.76 & 9.81 & .46 \\
\hline & Tanah Merah & 19.80 & 72.90 & 43.10 & 38.40 & 43.36 & 7.66 & .48 \\
\hline & Elphil & 19.70 & 61.10 & 45.60 & 49.00 & 44.80 & 6.97 & .35 \\
\hline & Keseluruhan & 15.30 & 72.90 & 44.60 & 48.20 & 43.93 & 9.03 & .24 \\
\hline
\end{tabular}

malah nisbah kompos kepada EFB turut terjejas dengan SDP telah menetapkan nisbah tersebut sebanyak $70 \%$ (1 tan metrik EFB $=0.7$ tan metrik kompos). Selain itu, loji kompos perlu mengusahakan penambahan ruang khas untuk proses pemeraman yang tidak terdedah kepada air serta berlantaikan konkrit bagi mengelakkan serapan yang mengakibatkan kandungan kelembapan meningkat.

Loji kompos yang beroperasi di bawah bumbung dengan keluasan yang terhad iaitu sebanyak 4300-6500 $\mathrm{m}^{2}$ tidak membolehkan loji tersebut menerima lebih kuantiti EFB dan POME. Oleh itu, ia memerlukan langkah penyelesaian yang agresif dengan memendekkan lagi masa pengkomposan berbanding sekarang selama 45 hari.

Langkah terbaik dengan ruang yang minimum ialah memilih teknologi baru iaitu pra-rawat EFB menggunakan ketuhar gelombang mikro yang berfungsi membuang lignin dan memecahkan selulosa dan hemiselulosa (Ethaib et al. 2015). Beberapa penyelidik menunjukkan hasil analisis komposisi lignin, selulosa dan hemiselulosa seperti dalam Jadual 7. Terdapat perbezaan hubungan antara lignin, selulosa dan hemiselulosa dalam ikatan kompleks EFB lignoselulosa. Ia merangkumi ikatan eter, hidrogen dan ester (Harmsen et al. 2010). Lignin ialah polimer semula jadi yang paling kompleks. Struktur sebenarnya masih belum dikenal pasti. Secara amnya lignin ialah heteropolimer yang tiada bentuk tertentu, tidak larut dalam air dan kelihatan tidak aktif. Struktur asas kimianya ialah dalam unit fenilpropana (Harmsen et al. 2010).

Komponen utama dalam fiber EFB ialah selulosa yang merangkumi $35 \%$ bt. Selulosa ialah polisakarida semula jadi yang selari secara individu dengan unit D-glukopiranosa serta berhubung bersama dengan ikatan $\beta$-1,4-glikosida (Rosnah et al. 2006). Ia adalah organik dan mempunyai formula $\mathrm{C}_{6} \mathrm{H}_{10} \mathrm{O}_{5}$ dan struktur hasaberhablur. EFB mikrofiber selulosa (terbentuk melalui rantaian polimer yang kandungannya terikat kukuh, kawasan berhablur), adalah terbenam di dalam matriks hemiselulosa dan lignin (Doherty et al. 2011)

Hemiselulosa ialah polimer karbohidrat kompleks dengan berat molekul lebih ringan berbanding selulosa. Umumnya, ia mengandungi asid D-xilosa, D-manosa, D-galaktosa, D-glukosa, L-arabinosa, 4-O-metilglukuronik, D-galakturonik dan D-glukuronik. Komponen asas pada mata kasar hemiselulosa ialah glukuronoksilan dengan glukomanan pula komponen utama kandungan dalamannya. Perbezaan utama hemiselulosa EFB dengan selulosa ialah hemiselulosa EFB bercabang dengan rantaian lateral yang pendek serta mengandungi pelbagai gula yang berbeza (Perez et al. 2002).

JADUAL 7. Komposisi lignin, selulosa dan hemiselulosa dalam EFB

\begin{tabular}{lc}
\hline Komponen & Komposisi $(\%)$ \\
\hline Lignin & $27.6-32.5$ \\
Selulosa & $41.3-45.0$ \\
Hemiselulosa & $25.3-33.8$ \\
\hline
\end{tabular}

Han et al. 2011; Kim et al. 2012; Richana et al. 2015; Yunus et al. 2010

\section{AGREGAT}

Agregat merujuk kepada jumlah nutrien bagi nitrogen, fosforus, kalium dan magnesium (Agregat $=\mathrm{N}+\mathrm{P}_{2} \mathrm{O}_{5}+$ $\mathrm{K}_{2} \mathrm{O}+\mathrm{MgO}$ ). Dalam kajian ini, JNAN ialah 6.5 (ditunjukkan pada garisan putus-putus pada Rajah 6). Merujuk kepada Jadual 8 , min sebanyak 8.67 dan mod 8.20 menunjukkan loji kompos telah mencapai $33 \%$ lebih tinggi berbanding nilai JNAN. Ianya amat penting jika JNAN yang diperoleh kurang daripada 6.5 , penalti akan dikenakan menyebabkan rebat bayaran yang merugikan loji kompos. Faktor utama yang menyumbang kepada agregat ialah nilai $\mathrm{N}$ dan $\mathrm{K}_{2} \mathrm{O}$ iaitu sebanyak $80 \%$. Hal ini disebabkan JNN bagi $\mathrm{N}$ ialah 1.8 dan $\mathrm{K}_{2} \mathrm{O}$ iaitu 3.4 adalah tinggi (5.2/6.5). Berdasarkan Rajah 6, loji kompos hanya menghadapi agregat rendah pada awal tahun 2014 yang disumbangkan oleh Merotai, Tanah Merah dan Elphil. Namun pada Julai 2014 sehingga 2015, loji tersebut telah mengatasi masalah tersebut melalui peningkatan nilai $\mathrm{N}$ dan $\mathrm{K}_{2} \mathrm{O}$.

\section{KESIMPULAN}

Selepas membuat analisis keempat-empat loji kompos tersebut dan berdasarkan data 3 tahun yang bermula dari tahun 2013 sehingga 2015 mendapati cabaran utama yang dihadapi oleh loji kompos ialah nilai KK yang agak tinggi dan nilai $\mathrm{K}_{2} \mathrm{O}$ yang tidak stabil. Komponen ini amat penting dalam penghasilan kompos bagi memenuhi keperluan nutrien untuk perkembangan pokok kelapa sawit. Loji kompos perlu mengusahakan penambahan ruang khas untuk proses pemeraman yang tidak terdedah kepada air serta berlantaikan konkrit bagi mengelakkan serapan air yang mengakibatkan kandungan kelembapan meningkat. 
JADUAL 8. Nilai agregat kompos yang dihasilkan mengikut loji kompos 2013-2015

\begin{tabular}{llccccccc}
\hline & & & \multicolumn{3}{c}{ Agregat } \\
\cline { 3 - 8 } & & Minimum & Maksimum & Median & Mod & Min $\begin{array}{c}\text { Sisihan } \\
\text { piawai }\end{array}$ & $\begin{array}{c}\text { Min ralat } \\
\text { piawai }\end{array}$ \\
\hline \multirow{2}{*}{ Loji } & Binuang & 6.10 & 13.34 & 8.45 & 8.71 & 8.70 & 1.60 & .09 \\
& Merotai & 5.69 & 11.77 & 8.33 & 8.18 & 8.46 & 1.14 & .05 \\
& Tanah Merah & 2.11 & 13.40 & 7.63 & 8.20 & 7.90 & 1.98 & .12 \\
& Elphil & 5.45 & 14.97 & 9.44 & 8.57 & 9.38 & 1.52 & .08 \\
& Keseluruhan & 2.11 & 14.97 & 8.51 & 8.20 & 8.67 & 1.61 & .04 \\
\hline
\end{tabular}

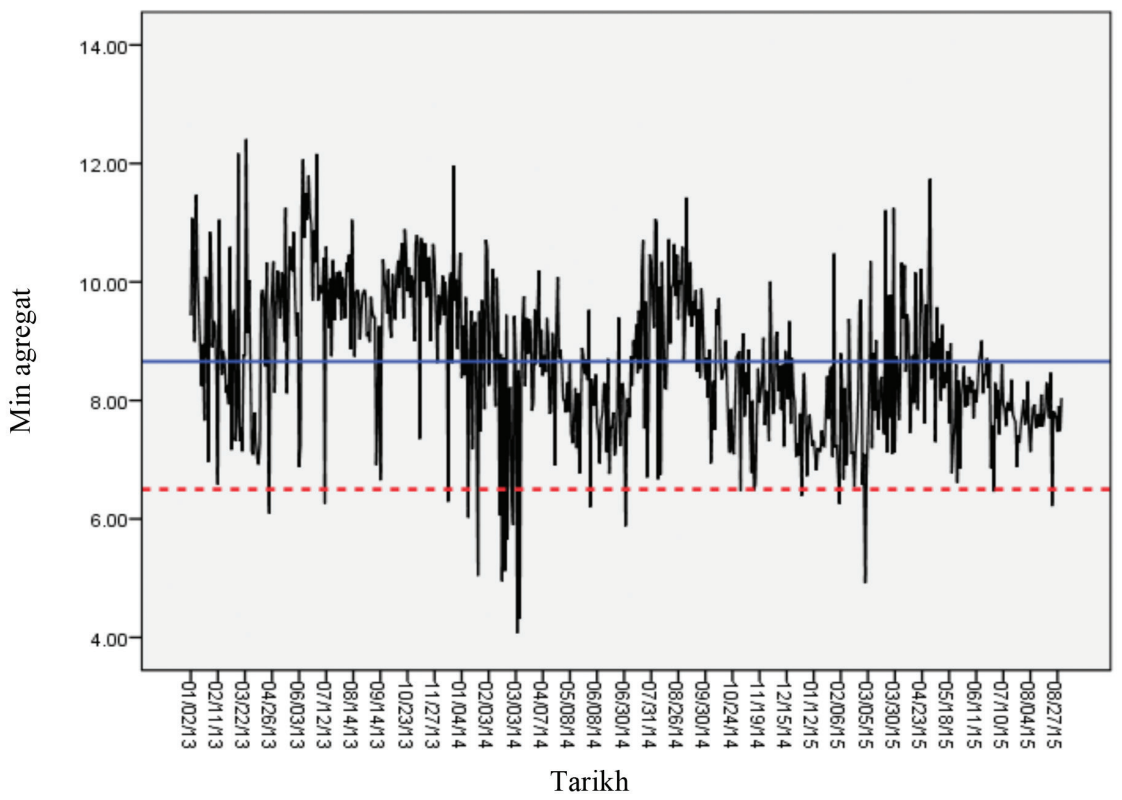

RAJAH 6. Min keseluruhan agregat oleh empat loji kompos (2013-2015)

KK yang tinggi ( $>50 \%$ ) bukan sahaja menambahkan berat kompos malah nisbah kompos kepada EFB turut terjejas dengan SDP telah menetapkan nisbah tersebut sebanyak $70 \%$ (1 tan metrik EFB $=0.7$ tan metrik kompos $)$.

Loji kompos yang beroperasi di bawah bumbung dengan keluasan yang terhad iaitu sebanyak 4300-6500 $\mathrm{m}^{2}$ tidak membolehkan loji tersebut menerima lebih kuantiti EFB dan POME. Oleh itu, ia memerlukan langkah penyelesaian yang konkrit dengan mengurangkan lagi masa pengkomposan berbanding sekarang selama 45 hari. Langkah terbaik dengan ruang yang minimum ialah memilih teknologi baru iaitu pra-rawat EFB menggunakan ketuhar gelombang mikro yang berfungsi memecahkan struktur degil lignin bagi memudahkan bakteria menghadam selulosa dan hemiselulosa (Ethaib et al. 2015). Dengan sistem pengkomposan yang diamalkan sekarang masih terdapat peluang untuk menghasilkan kompos secara pelet dan ia lebih mudah diuruskan terutamanya ketika proses pembajaan dalam ladang serta KK juga sentiasa terkawal. Terdapat sesetengah substrat juga boleh digunakan sebagai bahan penambah untuk memperkayakan lagi nutrien dalam proses kompos seperti kulit pisang (Zahrim et al. 2015), ikan bilis kering, cendawan dan daun sawit.

\section{PENGHARGAAN}

Setinggi-tinggi penghargaan diucapkan kepada pengarah urusan Prestige Central Management Sdn. Bhd iaitu Tuan Haji Hashim Mad Aris dan Tuan Syed Adeli Syed Amir kerana memberi peluang dan bantuan dalam menjalankan kajian serta proses pengumpulan data.

\section{RUJUKAN}

Bakar, R.A., Darus, S.Z., Kulaseharan, S. \& Jamaluddin, N. 2011. Effects of ten year application of empty fruit bunches in an oil palm plantation on soil chemical properties. Nutrient Cycling in Agroecosystems 89(3): 341-349.

Bhattacharyya, P., Chakrabarti, K., Chakraborty, A., Nayak, D.C., Tripathy, S.\& Powell, M.A. 2007. Municipal waste compost as an alternative to cattle manure for supplying potassium to lowland rice. Chemosphere 66(9): 1789-1793.

Buron, M., Frappé, M., Erales, R., Mario, J. \& Rivera, C. 2010. Composting of EFB and POME: Operational records compared to existing literature. In PORIM International Palm Oil Conference. pp. 1-8.

Doherty, W.O.S., Mousavioun, P. \& Fellows, C.M. 2011. Valueadding to cellulosic ethanol: Lignin polymers. Industrial Crops and Products 33: 259-276. 
Ethaib, S., Omar, R., Kamal, S.M.M. \& Biak, D.R. 2015. Microwave-assisted pretreatment of lignocellulosic biomass: A review. Journal of Engineering Sciene and Technology (Special Issue on SOMCHE 2014 \& RSCE 2014 Conference): 97-109.

Harmsen, P.F.H., Huijgen, W.J.J., Lopez, L.M.B. \& Bakker, R.R.C. .2010. Literature Review of Physical and Chemical Pretreatment Processes for Lignocellulosic Biomass. Netherlands: Energy Research Centre of the Netherlands.

Ooi, H.S. 2011. Zero discharge composting of palm oil mill wastes. The Institution of Engineers, Malaysia 72(3): 51-55.

Jusoh, M.L.C., Manaf, L.A. \& Latiff, P.A. 2013. Composting of rice straw with effective microorganisms (EM) and its influence on compost quality. Iranian Journal of Environmental Health Science \& Engineering 10(1): 17. doi. org/10.1186/1735-2746-10-17.

Kavitha, B., Jothimani, P. \& Rajannan, G. 2013. Empty fruit bunch-A potential organic manure for agriculture. International Journal of Science, Environment and Technology 2(5): 930-937.

Li, Y., Li, W., Liu, B., Wang, K., Su, C. \& Wu, C. 2013. Ammonia emissions and biodegradation of organic carbon during sewage sludge composting with different extra carbon sources. International Biodeterioration and Biodegradation 85: 624-630.

Malakahmad, A., Lahin, F.A. \& Yee, W. 2014. Biodegradation of high-strength palm oil mill effluent (POME) through anaerobes partitioning in an integrated baffled reactor inoculated with anaerobic pond sludge. Water, Air, and Soil Pollution 225: 1883.

Norhasmillah,A.H., Puah, C.W., Ibrahim, N.A., Baharuddin, A.S. \& Choo, Y.M. 2013. Life cycle inventory of the commercial production of compost from oil palm biomass: A case study. Environment, Development and Sustainability 15(6): 16631670.

Perez, J., Munoz-Dorado, J., Rubia, T.D.L. \& Martinez, J. 2002. Biodegradation and biological treatments of cellulose, hemicellulose and lignin: An overview. Int. Microbiol. 5(2): 53-63.

Schuchardt,F. \& Stichnothe,H. 2008. Zero waste process for palm oil mills by composting and biological drying. In Manure and Organic Residues Management Approaches in Non-European Countries. http://www.academia.edu/3742257/Manure_ and_organic_residues_management_approaches_in_nonEuropean_countries_SLURRY_MANAGEMENT_IN_ DAIRY_GRAZING_FARMS_IN_SOUTH_AMERICAN_ COUNTRIES.

Singh, R.P., Ibrahim, M.H., Esa, N. \& Iliyana, M.S. 2010. Composting of waste from palm oil mill: A sustainable waste management practice. Reviews in Environmental Science and Biotechnology 9(4): 331-344.

Veijalainen, A.M., Juntunen, M.L., Lilja, A., Heinonen-Tanski, H. \& Tervo, L. 2007. Forest nursery waste composting in windrows with or without horse manure or urea - The composting process and nutrient leaching. Silva Fennica 41(1): 13-27.
Wu, T.Y., Mohammad, A.W., Jahim, J.M. \& Anuar, N. 2009. A holistic approach to managing palm oil mill effluent (POME): Biotechnological advances in the sustainable reuse of POME. Biotechnology Advances 27(1): 40-52.

Yan, Z., Song, Z., Li, D., Yuan, Y., Liu, X. \& Zheng, T. 2015. The effects of initial substrate concentration, $\mathrm{C} / \mathrm{N}$ ratio, and temperature on solid-state anaerobic digestion from composting rice straw. Bioresource Technology 177: 266-273.

Zahrim, A.Y. 2005. Pengkomposan enapcemar perawatan air sisa industri. Tesis Sarjana. Universiti Kebangsaan Malaysia (tidak diterbitkan)

Zahrim,A.Y.\& Asis, T. 2010. Production of non shredded empty fruit bunch semi-compost. The Institution of Engineers, Malaysia 71(4): 11-17.

Zahrim, A.Y., Asis, T., Hashim, M.A., Al-Mizi, T.M.A.T.M. \& Ravindra,P. 2015. A review on empty fruit bunch composting: Life cycle analysis and the effect of amendment(s). In Advance in Bioprocess Technology, edited by Ravindra, P. Cham: Springer. pp. 3-15. doi.org/10.1007/978-3-31917915-5_1.

Zainudin, M.H.M., Hassan, M.A., Tokura, M. \& Shirai, Y. 2013. Indigenous cellulolytic and hemicellulolytic bacteria enhanced rapid co-composting of lignocellulose oil palm empty fruit bunch with palm oil mill effluent anaerobic sludge. Bioresource Technology 147: 632-635.

Asis, T.*

Prestige Central Management Sdn Bhd

73M, 73A \& 77B, Jalan SS21/37, Damansara Utama

47400 Petaling Jaya, Selangor Darul Ehsan

Malaysia

Zahrim, A.Y.

Fakulti Kejuruteraan

Universiti Malaysia Sabah, Jalan UMS

88400 Kota Kinabalu, Sabah Negeri di Bawah Bayu

Malaysia

Assis, K.

Fakulti Sains dan Sumber Alam

Universiti Malaysia Sabah, Jalan UMS

88400 Kota Kinabalu, Sabah Negeri di Bawah Bayu Malaysia

*Pengarang untuk surat-menyurat; email: asis.tahang@gmail. com

Diserahkan: 18 Mac 2016

Diterima: 1 Februari 2017 